\author{
Martin RUSEK ${ }^{1 *}$, Kateřina CHROUSTOVÁ ${ }^{1}$, Martin BÍLEK $^{1}$, Petr A. SKŘEHOT ${ }^{2}$ \\ and Zdeněk HON ${ }^{3}$
}

\title{
CONDITIONS FOR EXPERIMENTAL ACTIVITIES AT ELEMENTARY AND HIGH SCHOOLS FROM CHEMISTRY TEACHERS' POINT OF VIEW
}

\begin{abstract}
School experiments represent a necessary means of subject-matter presentation in chemistry education and are important for chemical (scientific) thinking. Despite being a focus of several texts, a complex view on the experimental activity in chemistry education in Czechia is missing. The results of a questionnaire survey among 466 lower-secondary, lyceum and grammar school teachers focused on types of conducted experiments, their frequency, the place they are conducted. The most frequently used chemicals and sources of inspiration are presented in the paper. The results show that despite experiments' significant role in education, its occurrence is rather seldom and teacher's demonstrations prevail over students' experiments. The list of the most often used chemicals suggests the experiments are mostly focused on inorganic chemistry. These results open further questions regarding occupational safety at schools as an important factor which could also be the reason for such a low representation of experiments in Czech chemistry education.
\end{abstract}

Keywords: experimental activity, chemistry teacher, lower-secondary school, general chemistry education

\section{Introduction}

Education in chemistry as an empirical scientific discipline is closely linked with experimental activity. School experiments, or educational experiments, are a necessary part of chemistry education [1-4]. Without it, chemistry education loses its original character. Chemistry differs from other scientific disciplines by its considerable part focused on the sub-microscopic composition of the world, see [5,6]. This, naturally, brings a certain amount of abstraction to students, especially at the end of their lower-secondary education (14-15 year-olds) when chemistry is being taught that they may not be capable of [7]. A trend to visualize as much as possible [8] is understandable. Above all, with a focus on formulas and other symbols dominating, chemical (scientific) thinking [9] the school subject does not even fulfil its curricular purpose. It is too difficult and demotivating for students [10-12].

\footnotetext{
${ }^{1}$ Faculty of Education, Charles University, Magdalény Rettigové 4, 11639 Prague 1, Czech Republic, email: martin.rusek@pedf.cuni.cz,katerina.chroustova@pedf.cuni.cz, martin.bilek@pedf.cuni.cz

${ }^{2}$ Safety and Health Expert Institute, Raichlova 2659/2, 15500 Prague 5, Czech Republic, email: skrehot@zuboz.cz

${ }^{3}$ Faculty of Biomedical Engineering, Czech Technical University in Prague, Sportovců 2311, 27201 Kladno, Czech Republic, email: zdenek.hon@fbmi.cvut.cz

*Corresponding author: martin.rusek@pedf.cuni.cz
} 
A chemical experiment is a suitable tool which connects basic chemical education's components. It is both a tool for demonstrating elements or compounds' properties and enables the development of scientific thinking or scientific literacy [13], which is supposed to be a part of chemical education too [14].

Scientific literacy as a concept promoted namely by the Programme for International Student Assessment (PISA), has been seen as a goal of science education by the Organization for Economic Co-operation and Development (OECD) [15]. In the PISA project, scientific literacy is defined by three pillars: explaining phenomena scientifically, evaluate and engineer scientific research and interpret data and evidence scientifically [15]. Despite theoretical teaching focused on delivering facts may partly cover scientific literacy development, doing experiments is essential. Not only is it the sole method for students to learn to design and evaluate experiments. It also shows the need to use proper scientific terms in a relevant context [16] and supports research data interpretation.

It is namely in experiment-related skills that Czech students lag behind the average of students from OECD countries [15, 17]. Developing this area is therefore necessary. Its presumption is, however, precise performance in the experiment, which leads to an educational effect not only a show. Activating students' thinking is vital at this point. It can be induced by questions and tasks in the broad sense of the word. Exaggerated abstraction or use of complicated compounds and their chemical reactions can seem attractive, however, can disrupt an experiment's transparency and therefore significantly lower its contribution for students [18].

Out of different levels of education, the above-mentioned situation concerns mostly the types of schools where chemistry belongs among school subjects of general education. Schools whose curricula are science or chemistry-oriented naturally approach experimental activities differently. From this point of view, in Czechia this concerns lower-secondary schools, grammar schools and certain levels of vocational schools including lycea. The state curricula for these schools are mostly traditional $[14,19]$ and as seen in $[19,20]$ are comparable with curricula in other countries. Also, the school system with respect to chemistry education is in many ways similar to others in the world [21]. For this reason, the problem this research was aimed at is of an international interest.

This topic's importance is further stressed by recently published papers in which the authors dealt with technical tools, equipment and material for experimental activities $[22,23]$, differences between virtual and real experiments' effectiveness [13, 24, 25], and experiments as part of project-based or inquiry-based education [2, 26]. A complex overview of the situation in schools is, however, missing.

The presented research was therefore motivated by the need to get more detailed information in this area fundamental for chemistry education.

\section{Goals and methods}

\section{Goals}

Before taking any steps toward improvement of this nonideal situation, the current status quo needs to be known. The goal of this research was to map the field of school chemical experiments in Czech schools where chemistry is being taught as a subject in a general education (i.e. lower-secondary schools, grammar schools and lycée).

The research was directed by the following research questions:

1. What types of experiment are being conducted at schools and in what frequency? 
2. Where does the experimental activity take place in schools?

3. Where do teachers get the inspiration for chemistry experiments and how do they evaluate them?

4. Which chemical compounds do teachers use the most often for experimental activities?

\section{The research tool}

A questionnaire survey was used as the research method. The questionnaire items were constructed with respect to the goals of project TL02000226 "Evaluation of Safe Practice Teaching Practices in Schools". It was piloted among the project team members as well as with 18 chemistry teachers who had previously cooperated with the team members. The questionnaire was created in the $1 \mathrm{Ka}$ app. The data collection took from June 2019 to March 2020.

\section{Sample}

The sample of this study was formed by chemistry teachers in lower-secondary schools (LS), grammar (G) schools and lycea (L) in Czechia. The sample was stratified, respecting the minimum sample size (according to an online sample size calculator Raosoft.com) derived by the number of teachers in particular regions in Czechia.

From the Czech Ministry of Education, Youth and Sports' address book [27], several types of school were excluded: special schools, apprentice/vocational schools, practical schools and all schools without chemistry education. Further, the schools were selected according to their location. At selected schools, all chemistry teachers or teachers who teach chemistry were addressed.

\section{Data analysis}

The data were analysed directly in the $1 \mathrm{Ka}$ and partly in MS Excel. The answers on scales were assigned numeric values ( 1 - every lesson, 5 - never). For this reason, the data were treated as ordinal.

\section{Results and discussion}

\section{Information about respondents}

Partial, yet usable, information was provided by 466 teachers. 354 teachers completed the whole questionnaire. The sample contains 302 lower-secondary, 222 grammar school teachers and 21 lyceum chemistry teachers. 79 teachers answered that they teach at two types of school. In this case their answers were analysed in both teacher categories. A typical respondent for the research is a female teacher $(80.7 \%)$ with more than 20 years of practice $(51.9 \%)$ who has a degree in chemistry education $(76.2 \%)$ - the details are shown in the Supplement. With respect to the estimated number of chemistry teachers in lower-secondary schools and a similar recomputation for grammar schools is the number of participants above the minimal sample.

\section{Experiments at lower-secondary, grammar schools and lycea}

Types of experiments and places they are being conducted

According to the respondents, Czech students encounter mostly teacher-performed demonstrations. At LS and G, experiments are done at least once a month. Students' 
experiments are less frequent. Whereas at LS and L the teachers mentioned doing experiments less than once a month, $G$ teachers answered that they do experiments at least once a month.

Teacher education did not prove to be a factor. Similar results were reached when the answers were analysed according to the length of the teachers' practice. The only deviation was indicated among the teachers with teaching practice shorter than three years, who mentioned doing demonstrations more often than once a month $(\mathrm{Med}=2.5)$. This result could be interpreted as the novice teachers' initial motivation and their application of the teaching approach they bring from universities.

In this respect, school conditions proved to be an important factor. Information about them provide interpretation of the students' experiments higher frequency. At LS, experiments are conducted in specialized chemistry classrooms $(72 \%)$ and in $28 \%$ in a common classroom. Only $18 \%$ of the respondents mentioned they have a laboratory. Naturally, this greatly affects the type of experiments which can be conducted. As anticipated, the situation is better at grammar schools. $22 \%$ of experiments are done in a common classroom, whereas $76 \%$ in a specialized classroom. On top of that, $93 \%$ of teachers mentioned they do experiments in a laboratory. At lycea, $29 \%$ of the teachers mentioned doing experiments in a common classroom, $41 \%$ accordingly mentioned conducting experiments either in a specialized classroom or a laboratory. These results naturally unreel from the curricula at the particular type of schools. With respect to the above presented results, it can be concluded that experimental activities are quite rare. Considering the importance of experiments in chemistry education, especially their effect on scientific literacy development, this finding is a call for a change. This result is however, in accordance with the line of argumentation in [22], when promoting experimental activities by introducing experimental sets as a laboratory or chemical stores.

A teacher's field of study proved to be a factor in the case of laboratory experiments. Whereas experiments in laboratories are done by $31 \%$ of teachers who studied chemistry or chemistry education, only $10 \%$ of teachers who studied a different field mentioned doing laboratory experiments. This is probably caused by the teachers' experience with experimental activities as well as the image of chemistry education they bring from their university studies.

The length of teachers' practice was proven only partially. The number of teachers who do experiments in a specialized classroom grows with increasing length of their practice. The teachers' experience then seems to have an effect. To assess the quality of these experiments, however, the classes would need to be visited and evaluated individually as there is a great difference between showing a reaction and conducting an educational chemistry experiment.

\section{Resources for experiments and the role of universities in experimental activity support}

There was an agreement noticed in the teachers from different types of schools regarding the sources of inspiration for experiments. They mentioned lower-secondary school textbooks $(18 \%)$, the internet $(18 \%)$ and seminars or courses $(15 \%)$. Compared to $\mathrm{G}$ teachers, LS teachers use textbooks and the internet more frequently. $\mathrm{G}$ teachers mentioned using lower-secondary and upper-secondary chemistry textbooks, whereas $\mathrm{L}$ teachers use lower-secondary textbooks only seldom. $\mathrm{L}$ teachers, similar to $\mathrm{G}$ teachers, mentioned using university mimeographed in $12 \%$. The role of textbooks proved to be still strong [28]. A deeper analysis of experiments presented in textbooks is, however, missing. 
As far as the resources are concerned, similar trends were also found from the point of view of teachers' length of practice. Lower-secondary chemistry textbooks and the internet are a domineering source, however, the use of university mimeographed decreases after five years of teachers' teaching practice from 16 to $8 \%$. The influence of university on these teachers seems to disappear with teachers gaining experience. In the group of teachers with less than three years teaching practice, there was the lowest ratio of teachers who mentioned seminars and courses to be sources of inspiration. This could, in contrast to the above mentioned, be given by their contact with university so far as they do not seem to seek any further education. The field of study did not prove to be a factor in this case.

Similar findings came out of the teachers' responses regarding teacher training. They would welcome a more detailed pre-service training $(48 \%)$ or further in-service training $(31 \%)$. Fewer than $13 \%$ of the respondents mentioned they consider university activities sufficient.

Greater activity from universities, even during their pre-service training, would be welcomed by $50 \%$ of the LS teachers, c. $40 \% \mathrm{G}$ teachers and $52 \% \mathrm{~L}$ teachers. Within in-service training, more training would be welcome by $26 \%$ of LS teachers, $33 \% \mathrm{~L}$ and $40 \% \mathrm{G}$ teachers.

When the last three items are put together, a potential risk of the educational system is revealed. The teachers seem to conserve themselves in their own practice as far as the teaching materials are concerned. The responses can be read as their overall attitude towards teacher training. They consider pre-service training important, however as far as the follow-up training or use of materials are concerned, majority of them seem to stay out of any reach, therefore indifferent to any modernizing attempts. There are two-thirds of teachers who consider in-service training not important with only c. $20 \%$ of the teachers acting like prospective target group for teacher development courses. This result was surprising as teachers were reported to understand chemistry experiments only to some extent [29].

Also, activities such as annual conferences, chemistry teachers' science fair or presently offered courses seem insufficient. Apart from the teachers' apparent negative attitude towards external support, this may be given by their face-to-face conception, whereas teachers might welcome online courses. Another possibility is that the activities are not advertised to teachers enough. These suppositions need to be confirmed.

Almost $40 \%$ of LS chemistry teachers with up to three years practice consider their skills regarding experimental practice sufficient. Given the fact these teachers mostly come directly from universities, the low confidence is striking and gives universities a hint what to improve. This could serve as an explanation to the low frequency of doing chemistry experiments in schools, considering the fact $60 \%$ of the teachers consider their experimental skills less than sufficient. On the other hand, teachers with longer practice mentioned they would welcome more experiment-related training even during their pre-service training. This could be translated as chemistry teachers' appeal towards the chemistry teacher training programmes. Another variant is also possible. Standard courses such as "Inorganic chemistry laboratory" or "Organic chemistry laboratory" could be, as far as both their content and conception are concerned, targeted towards actual activities which could be performed in lower- or upper-secondary chemistry teaching practice. 


\section{The most frequently used compounds for experimental activity}

More detailed information about the school experimental practice can be found in the compounds teachers use in their practice (Fig. 1). The teachers were asked to write five chemicals they use the most. The frequencies of their mentioning were expressed as a ratio, so the numbers correspond to the number of teachers in a particular group. The data suggest that only a limited palette of chemicals is being used. Some teachers wrote more than five, some were more general (mentioning acids, bases, metals, etc.) instead of concrete compounds. There was not an obvious connection between the chemicals teachers mentioned. However, they suggest the experiments which the teachers conduct. The results show that experimental activity is strongly focused on general or inorganic chemistry. Only in single percentages did the teachers mention organic compounds (ethanol, methanol, toluene and acetone). G and L teachers mentioned using organic compounds only seldom.

Another line of necessary research showed up in this respect. More valuable information would be received if the teachers were asked to name concrete experiments they perform. This, however, calls for a separate research as experiments and demonstrations (and teachers' perception of their difference) need to be considered in order to estimate the educational potential.

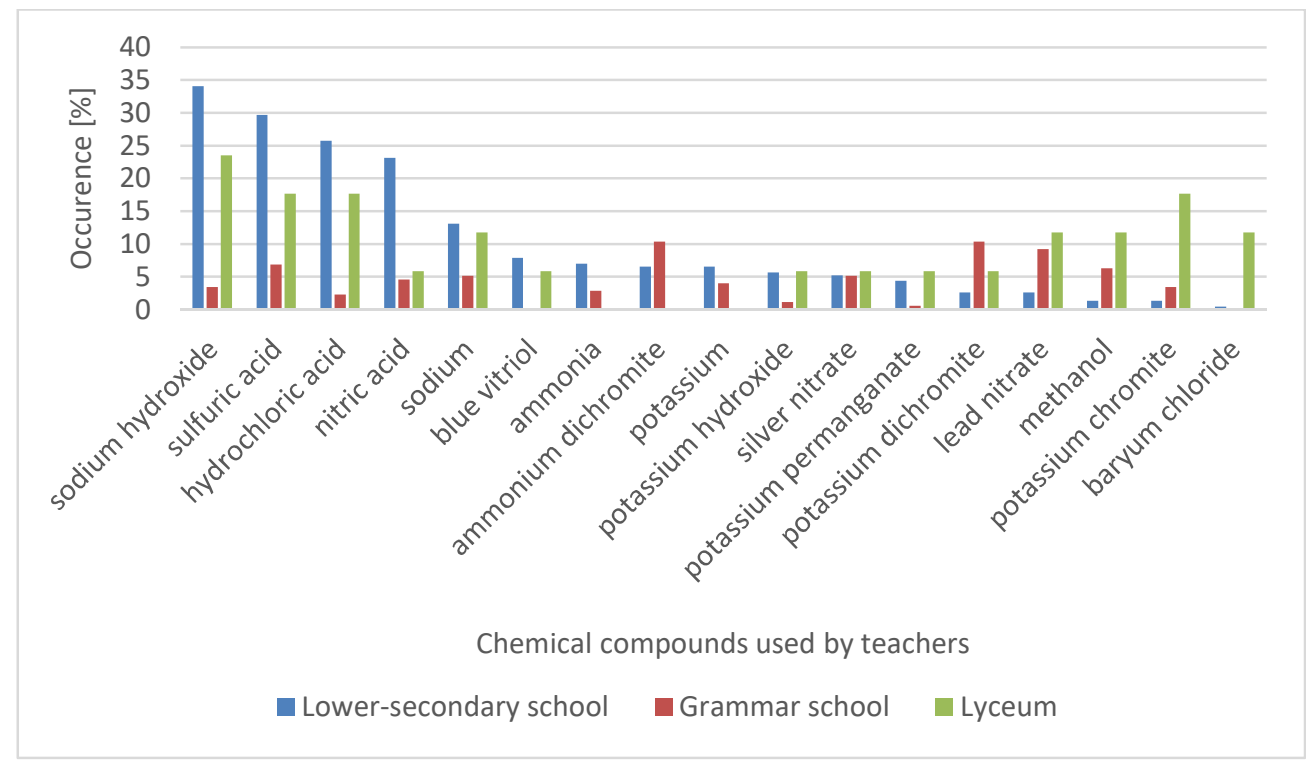

Fig. 1. The most frequently used chemicals according to the types of school

\section{Conclusion}

The results of the survey showed that chemistry at Czech schools is only seldom accompanied by experiments. It is, however, a vital part of the field as both a source of new knowledge as well as a teaching method which allows students' deeper contact with studied phenomena and processes. The need to support this part of chemistry education is also further stressed by Czech students' poor international results comparison in this area [17]. 
Another vital finding is the teachers see reserves in pre-service chemistry teacher training. Once in practice, only a minority of them seeks for further development. A considerable role of textbooks on teachers' experiment choice was found. Having no deeper understanding to the types of textbook experiments as well as their quality, there was a new line of important research identified.

Experimental activities are mostly organized in chemistry classrooms at lower-secondary schools and lycea. Grammar schools usually dispose of more laboratories. As far as the used chemicals are concerned, the results show a strong focus on general or inorganic chemistry as well as demonstrations. This could be changed by universities' greater accent on experimental activities as a part of teacher training, which is also one of the appeals the respondent teachers expressed.

The results of this research need to be interpreted considering several limiting factors. The sample selection was not random, it is merely a saturated minimum sample mirroring the teachers' population in particular districts in Czechia. For this reason, the information could be influenced by a greater statistical error. On the other hand, the presented data are mostly of a descriptive character. The teachers who were willing to participate are expected to be the more active and communicable. The presented data may therefore present "a nicer picture" than reality. The research method enabled us to obtain information from quite a numerous sample, nevertheless, to describe educational reality would require lesson observations and experiment analysis along with interviews with teachers and students. Also, the questions about the most frequently used chemicals contained five textboxes. This could, in a way, limit the results. However, the teachers' responses did not suggest greater variability in the chemicals they use. Several of them did not even use all five fields.

The research also included a part focused on occupational safety during experimental activities. These results, however, extend the scope of this paper and will be published separately.

\section{Acknowledgements}

The results published in this paper were gathered within the project TL02000226 "Evaluation of Safe Practice Teaching Practices in Schools" supported by the Technological agency of the Czech Republic.

\section{References}

[1] Tatli Z, Ayas A. J Educ Tech Soc. 2013;16:159-70. Available from: https://www.jstor.org/stable/pdf/ jeductechsoci.16.1.159.pdf.

[2] Rusek M, Beneš P, Carroll J. J Chem Educ. 2018;95:1018-21. DOI: 10.1021/acs.jchemed.7b00110.

[3] Reid N, Shah I. Chem Educ Res Pract. 2007;8:172-85. DOI: 10.1039/B5RP90026C.

[4] Bretz SL. J Chem Educ. 2019;96:193-5. DOI: 10.1021/acs.jchemed.8b00874.

[5] Johnstone AH. J Comp As Learn. 1991;7:75-83. DOI: 10.1111/j.1365-2729.1991.tb00230.x.

[6] Talanquer V. Int J Sci Educ. 2011;33:179-95. DOI: 10.1080/09500690903386435.

[7] Piaget J. The Construction of Reality in the Child. London: Routledge Kegan Paul; 2013. ISBN: 0415210003.

[8] Gašparík V, Prokša M, Drozdíková A. Chem Didact Ecol Metrol. 2017;22:69-91. DOI: 10.1515/cdem-2017-0004.

[9] Gasparatou R. Scientism and Scientific Thinking. Sci Educ. 2017;26:799-812. DOI: 10.1007/s11191-017-9931-1.

[10] Salta K, Tzougraki C. Sci Educ. 2004;88:535-47. DOI: 10.1002/sce.10134.

[11] Lay A-N, Osman K. J Educ Sci, Environ Health. 2018;4:81-92. DOI: 10.21891/jeseh.387499. 
[12] Osborne J, Dillon J. Science Education in Europe: Critical Reflections, London: The Nuffield Foundation; 2008. Available from: http://efepereth.wdfiles.com/local--files/science-education/Sci_Ed_in_Europe_ Report_Final.pdf.

[13] Unal M, Aral N. Educ Sci. 2014;39:279-91. DOI: 10.15390/EB.2014.3592.

[14] Vojîr K, Rusek M. Chem Listy. 2020;114:366-9. Available from: http://www.chemickelisty.cz/ojs3/index.php/chemicke-listy/article/view/3606/3552.

[15] OECD: PISA 2015 Results (Volume I): 2016. Available from: https://www.oecdilibrary.org/content/publication/9789264266490-en.

[16] Stuckey M, Hofstein A, Mamlok-Naaman R, Eilks I. Stud Sci Educ. 2013;49:1-34. DOI: 10.1080/03057267.2013.802463.

[17] Blažek R, Příhodová S. Mezinárodní šetření PISA 2015: národní zpráva: přírodovědná gramotnost: Česká školní inspekce (International Survey PISA 2015: The National Report: The Scientific Literacy); 2016. ISBN: 8088087082. Available from: https://www.csicr.cz/Csicr/media/Prilohy/PDF_el._publikace Mezinárodní\%20క̌etření/NZ_PISA_2015.pdf.

[18] Trna J. Výuková situace: Setrvačnost těles v jednoduchých experimentech ve fyzice (Teaching situation: Inertia of bodies in simple experiments in physics). Komenský. 2013;137:39-45. Available from: http://katedry.ped.muni.cz/pedagogika/wp-content/uploads/sites/17/2014/10/komensky_04_13.pdf.

[19] Elmas R, Rusek M, Lindell A, Nieminen P, Kasapoglu K, Bílek M. Chem Educ Res Pract. 2020;21:839-51. DOI: 10.1039/D0RP00058B.

[20] Urválková ES, Teplá M, Janoušková S. SciED. 2019;10:50-71. DOI: 10.14712/18047106.1293.

[21] Blonder R, Mamlok-Naaman R. Isr J Chem. 2019;59:625-34. DOI: 10.1002/ijch.201800100.

[22] Beneš P, Rusek M, Kudrna T. Chem Listy. 2015;109:159-62. Available from: http://www.chemickelisty.cz/ojs3/index.php/chemicke-listy/article/view/404/404.

[23] Ejidike IP, Oyelana AA. Int J Educ Sci. 2015;8:605-17. DOI: 10.1080/09751122.2015.11890282.

[24] Hensen C, Barbera J. J Chem Educ. 2019;96:2097-108. DOI: 10.1021/acs.jchemed.9b00561.

[25] Matlen BJ, Klahr D. Instr Sci. 2013;41:621-34. DOI: 10.1007/s11251-012-9248-z.

[26] Arsal Z. Int J Sci Educ. 2017;39:1326-38. DOI: 10.1080/09500693.2017.1329564.

[27] MŠMT. Available from: http://stistko.uiv.cz/registr/vybskolrn.asp.

[28] Vojî́r K, Rusek M. Int J Sci Educ. 2019;41:1496-516. DOI: 10.1080/09500693.2019.1613584.

[29] Drozdíková A, Prokša M. Chem Didact Ecol Metrol. 2016;21:45-52. DOI: 10.1515/cdem-2016-0003. 